J. Indian Chem. Soc.,

Vol. 71, June-August 1994, pp. 315-321

\title{
Heterometal Alkoxides as Precursors in the Sol-Gel Process
}

\author{
RAM C. MEHROTRA \\ University of Allahabad, Allahabad-211 002 \\ Manuscript recesved 13 September 1993
}

\begin{abstract}
The synthesis of bimetallic alkoxides has been followed by the preparation of intriguingly stable heterometal alkoxides containing three or four different metal atoms in the same molecular species, which has led to the possibility of molecularly designing a single source precursor suited to the composition of the targeted final ceramic. This has been made feasible by the extraordinary stability of the framework of heterometal alkoxides, which appears to remain intact during the initial hydrolysis reactions in the S-G process.
\end{abstract}

The characterisation (by sophisticated physicochemical techniques including $X$-Ray crystal structure elucidation in some cases) of heterometal alkoxides appears to have added a new dimension to heterometal coordination systems which appear to be uniquely stable without the presence of metal-metal bonds or auxiliary ligands like $\mathrm{CO}$, etc., enerally required for stabilising polymetallic systems known so far.

The term 'Heterometal Alkoxides' has itself a historical perspective reflecting the development of their chemistry also. Beginning with the evidence' for formation of the 'alkoxo salts', e.g. $\mathrm{Na}^{+}\left\{\mathrm{Al}(\mathrm{OR})_{4}\right\}^{-}$in the titration of basic alkali alkoxides with less electropositive metal alkoxides in nitrobenzene by Meerwein and Bersin ${ }^{1}$, a large number of so called 'double alkoxides' of various elements were synthesised in the research school of Mehrotra $^{2}$, including the characterisation of a few very interesting (from the point of view of volatility and solubility in organic solvents) examples, e.g. $\mathrm{NaZr}_{2}(\mathrm{OR})_{9}$, which had been described earlier by Bartley and Wardlaw ${ }^{3}$. The first review entitled 'Chemistry of double alkoxides of various elements' appeared ${ }^{2}$ in 1971, followed by a general survey ${ }^{4}$ of double alkoxides, and another review ${ }^{5}$ dealing with the chemistry of transition metal alkoxides.

The first tri-metallic alkoxides $\left(\mathrm{Pr}^{\prime} \mathrm{O}\right)_{2} \mathrm{Al}(\mu$ $\left.\mathrm{OPr}^{\prime}\right)_{2}\left(\mathrm{Be}\left(\mu-\mathrm{OPr}^{\prime}\right)_{2} \mathrm{Zr}\left(\mathrm{OPr}^{\jmath}\right)_{3}\right.$ and $\left(\mathrm{Pr}^{1} \mathrm{O}\right)_{2} \mathrm{Al}\left(\mu-\mathrm{OPr}^{\mathrm{l}}\right)_{2}$ $\mathrm{Be}\left(\mu-\mathrm{OPr}^{\prime}\right)_{2} \mathrm{Nb}\left(\mathrm{OPr}^{\prime}\right)_{4}$ were synthesised by Mehrotra and Agrawal $^{6}$ followed by the work on tri- and tetrametallic alkoxides of copper ${ }^{7}$ and other later transition metals ${ }^{8}$.
An interaction ${ }^{9}$ at the Fourth International Workshops on 'Glasses and Glass-Ceramics from Gels' (Kyoto, 1988) with Dislich ${ }^{10}$, who as early as 1971 had conjectured about the formation of such polymetallic complexes in the precursor solution of a mixture of many metal alkoxides, led to the first publication" entitled 'Polymetallic Alkoxides-Precursors for Ceramics' in which a variety of possible applications of such systems as precursors in the Sol-Gel process was envisaged by Mehrotra ${ }^{12}$. Realising that the term 'Polymetal Alkoxides' could be confused with the associated forms, like $\left\{\mathrm{M}(\mathrm{OR})_{\mathrm{n}}\right\}_{\mathrm{x}}$ of mono-metal systems, the term 'Heterometal Alkoxides' gradually came into use in a number of recent reviews ${ }^{13-19}$ and is now generally adopted for alkoxo species containing two, three. four or even five different metal atoms in the same molecular species.

In the following pages is presented a brief summary of the chemistry of heterometal alkoxides, laying particular emphasis on the achievements during recent years, as a number of reviews on the topic are available on the earlier work.

\section{Synthesis of Heterometallic Alkoxides}

Although a number of other procedures have 
also been exploited ${ }^{14}$ in special cases for synthesis of bimetallic alkoxides, only two main preparative routes which have been adopted in the research school of the author for the synthesis of a wide variety and large number of heterometal alkoxides as well as some allied derivatives, are being briefly summarised in the following two subsections.

\section{From the component alkoxides :}

Following the pioneering contributions of Meerwein ${ }^{1}$ and Wardlaw ${ }^{3}$, this method has been extensively employed ${ }^{20-22}$ for the synthesis of bimetallic alkoxides of alkali metals ( $\mathrm{Li}, \mathrm{Na}, \mathrm{K}$, $\mathrm{Rb}$ and $\mathrm{Cs}$ ) with a number of less electropositive metals like $\mathrm{Al}, \mathrm{Ga}, \mathrm{Sn}^{\mathrm{IV}}, \mathrm{Ti}, \mathrm{Zr}, \mathrm{Hf}, \mathrm{Ce}^{\mathrm{IV}}{ }^{23}$, $\mathrm{Th}, \mathrm{U}^{\mathrm{VI} 24}, \mathrm{Nb}^{\mathrm{V}}, \mathrm{Ta}^{\mathrm{V}}$ and $\mathrm{U}^{\mathrm{V} 25}$, etc. as illustrated by the following representative equations:

$$
\begin{aligned}
& \mathrm{MOR}+\mathrm{M}^{\prime}(\mathrm{OR})_{3} \rightarrow\left[\mathrm{M}\left\{\mathrm{M}^{\prime}(\mathrm{OR})_{4}\right\}\right] \\
& \left(\mathrm{M}=\mathrm{Li}, \mathrm{Na}, \mathrm{K}, \mathrm{Rb}, \mathrm{Cs} ; \mathrm{M}^{\prime}=\mathrm{Al}, \mathrm{Ga}, \mathrm{Fe} ;\right. \\
& \left.\mathrm{R}=\mathrm{Et}, \mathrm{Pr}^{\mathrm{i}}, \mathrm{Bu} \mathrm{u}^{\mathrm{t}}\right) \\
& \mathrm{MOR}+2 \mathrm{M}^{\prime}(\mathrm{OR})_{4} \rightarrow\left[\mathrm{M}\left\{\mathrm{M}_{2}^{\prime}(\mathrm{OR})_{9}\right\}\right] \\
& \left(\mathrm{M}=\mathrm{Li}, \mathrm{Na}, \mathrm{K} ; \mathrm{M}^{\prime}=\mathrm{Zr}, \mathrm{Th}, \mathrm{Ce}^{\mathrm{IV}}, \mathrm{U}^{\mathrm{IV}}, \mathrm{Sn}^{\mathrm{IV}} ;\right. \\
& \left.\mathrm{R}=\mathrm{Et}, \mathrm{Pr}^{\mathrm{i}}\right) \\
& \mathrm{MOR}+\mathrm{M}^{\prime}(\mathrm{OR})_{5} \rightarrow\left[\mathrm{M}\left\{\mathrm{M}^{\prime}(\mathrm{OR})_{6}\right\}\right]
\end{aligned}
$$$$
\left(M=L i, N a, K ; M^{\prime}=N b, T a, U ; R=M e, E t, \operatorname{Pr}^{i}, B{ }^{t}\right)
$$

Compared to the soluble alkoxides of univalent alkali metals, those of bivalent alkaline earth metals are much less soluble and their dissolution in alcohols is extremely slow (which may be due to formation of a superficial insoluble layer of the alkoxide on the metal). However, their dissolution in alcohols is appreciably accelerated by the presence of alkoxides of aluminium, niobium, zirconium, etc. By carrying out the reactions in the stoichiometric ratios indicated by the following equations, volatile soluble monomeric bimetallic alkoxides of alkaline earth metals $(\mathrm{M}=\mathrm{Mg}$, $\mathrm{Ca}, \mathrm{Sr}$ and $\mathrm{Ba}$ ) be easily synthesised ${ }^{20,21}$.

$$
\begin{aligned}
& \mathrm{M}+2 \mathrm{Pr}^{\mathrm{i}} \mathrm{OH}+2 \mathrm{M}^{\prime}\left(\mathrm{OPr}^{\mathrm{i}}\right)_{3} \rightarrow\left[\mathrm{M}\left\{\mathrm{M}^{\prime}\left(\mathrm{OPr}^{\mathrm{i}}\right)_{4}\right\}_{2}\right]+\mathrm{H}_{2} \\
& \left.\mathrm{M}+2 \mathrm{Pr}^{\mathrm{i}} \mathrm{OH}+4 \mathrm{M}^{\prime \prime}\left(\mathrm{OPr}^{\mathrm{i}}\right)_{4} \rightarrow\left[\mathrm{M}^{\prime \prime \prime} \mathrm{M}_{2}\left(\mathrm{OPr}^{\mathrm{i}}\right)_{9}\right\}_{2}\right]+\mathrm{H}_{2}
\end{aligned}
$$

$$
\begin{aligned}
& M+2 \operatorname{Pr}^{\mathrm{i}} \mathrm{OH}+2 \mathrm{M}^{\prime \prime}\left(\mathrm{OPr}^{\mathrm{i}}\right)_{5} \rightarrow\left[\mathrm{M}\left\{\mathrm{M}^{\prime \prime \prime}\left(\mathrm{OPr}^{\mathrm{i}}\right)_{6}\right\}_{2}\right]+\mathrm{H}_{2} \\
& \text { (where, } \left.\mathrm{M}^{\prime}=\mathrm{A} 1, \mathrm{Ga} ; \mathrm{M}^{\prime \prime}=\mathrm{Zr}, \mathrm{Hf} ; \mathrm{M}^{\prime \prime \prime}=\mathrm{Nb}, \mathrm{Ta}\right)
\end{aligned}
$$

It has been conjectured ${ }^{14}$ that this type of reaction is facilitated by the greater reactivity (due to higher acidity) of a complex species like $\mathrm{H}\left\{\mathrm{A} 1\left(\mathrm{OPr}^{\mathrm{i}}\right)_{4}\right\}$ between the alcohol and say, $\mathrm{Al}\left(\mathrm{OPr}^{\mathrm{i}}\right)_{3}$. All these bimetallic alkoxides of divalent metals are monomeric volatile species soluble in organic solvents, whereas the corresponding simple (monometallic) alkoxides of bivalent metals are generally polymeric, nonvolatile and insoluble in organic solvents. On the basis of their molecular weights and spectroscopic (mainly ${ }^{1} \mathrm{H}$ nmr) studies, these can be assigned simple formulations like $(\mathrm{RO})_{2} \mathrm{Al}(\mu-\mathrm{OR})_{2} \mathrm{M}(\mu-\mathrm{OR})_{2} \mathrm{Al}(\mathrm{OR})_{2}$.

On the basis of mass spectroscopic and nmr studies $^{26}$, a simple structure has been suggested for the bimetallic lanthanide tris-tetraisopropoxyaluminates (also synthesised in the laboratories of the author), which is quite similar to that of tetrameric aluminium isopropoxide, the structure of which has been eludicated by ${ }^{1} \mathrm{H}$ and ${ }^{27} \mathrm{Al}$ nmr studies, mass spectroscopy and actual $X$-ray structure $^{27}$.

Instead of $\mathrm{Y}\left(\mathrm{OPr}^{\mathrm{i}}\right)_{3}$ expected ${ }^{28}$ in the reaction of yttrium with isopropanol, a product characterised as $\mathrm{Y}_{5}\left(\mu_{5}-\mathrm{O}\right)\left(\mu_{3}-\mathrm{OPr}^{\mathrm{i}}\right)_{4}\left(\mu-\mathrm{OPr}^{\mathrm{i}}\right)_{5}$ has been isolated recently ${ }^{29}$ from the above reaction mixture. It has been further shown that this crystalline oxide-alkoxide does not react with $\mathrm{Al}\left(\mathrm{OPr}^{\mathrm{i}}\right)_{3}$ to yield $\left[\mathrm{Y}\left\{\left(\mathrm{Al}\left(\mathrm{OPr}^{\mathrm{i}}\right)_{4}\right\}_{3}\right]\right.$, which, however, can be distilled out in about $70 \%$ yield from the original reaction mixture after addition of $\mathrm{Al}\left(\mathrm{OPr}^{i}\right)_{3}$ to the same. This observation again points ${ }^{30}$ to the higher stability of the bimetallic isopropoxide, $\mathrm{Y}\left\{\mathrm{Al}\left(\mathrm{OPr}^{\mathrm{i}}\right)_{4}\right\}_{3}$.

In addition to bimetallic alkoxides of alkali, alkaline earth and lanthanide metals, syntheses of a few other bimetallic alkoxides have been reported from the mixtures of component alkoxides, e.g. 


$$
\begin{array}{lr}
\mathrm{Nb}_{2}(\mathrm{OMe})_{10}+\mathrm{Ta}_{2}(\mathrm{OMe})_{10} \rightarrow & \\
2(\mathrm{MeO})_{4} \mathrm{Nb}(\mu-\mathrm{OMe})_{2} \mathrm{Ta}(\mathrm{OMe})_{4} & (\text { Ref. 31) } \\
\mathrm{Zr}\left(\mathrm{OPr}^{1}\right)_{4} \cdot \mathrm{Pr}^{\mathrm{l}} \mathrm{OH}+2 \mathrm{Al}\left(\mathrm{OPr}^{1}\right)_{3} \rightarrow\left\{\left(\mathrm{Pr}^{1} \mathrm{O}\right)_{2} \mathrm{Al}\left(\mu-\mathrm{OPr}^{1}\right)_{2}-\right. \\
\left.\mathrm{Zr}\left(\mathrm{OPr}^{1}\right)_{2}\left(\mu-\mathrm{OPr}^{1}\right)_{2} \mathrm{Al}\left(\mathrm{OPr}^{1}\right)_{2}\right\} & (\text { Ref. 32) } \\
\mathrm{Nb}\left(\mathrm{OPr}^{1}\right)_{5}+2 \mathrm{Al}\left(\mathrm{OPr}^{1}\right)_{3} \rightarrow & \\
\quad\left\{\left(\mathrm{Pr}^{1} \mathrm{O}\right)_{3} \mathrm{Nb}\left(\mu-\mathrm{OPr}^{1}\right)_{2} \mathrm{Al}\left(\mathrm{OPr}^{1}\right)_{2}\right\}_{2} & (\text { Ref. 33) }
\end{array}
$$

From the reactions of metal halides (nitrates) with alkali alkoxometallates :

This route can be represented by the following illustrative reactions :

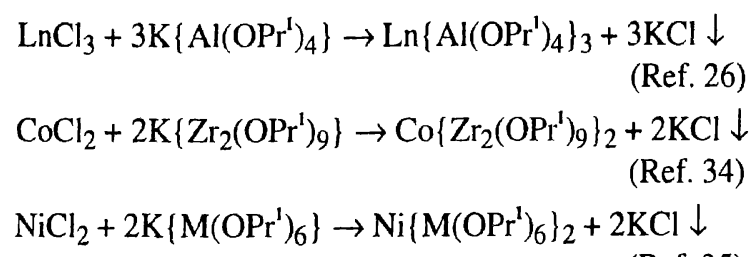

(Ref 35)

(where, $\mathrm{M}=\mathrm{Nb} / \mathrm{Ta}$ )

In fact, a wide variety of bimetallic alkoxides synthesised by the above route are represented by the following illustrative examples ${ }^{15}$ for an element ' $E$ ' of valency ' $n$ ' :

$$
\begin{aligned}
& \mathrm{E}\left\{\mathrm{M}\left(\mathrm{OPr}^{1}\right)_{4}\right\}_{\mathrm{n}} \quad \mathrm{E}\left\{\mathrm{M}^{\prime}\left(\mathrm{OPr}^{1}\right)_{6}\right\}_{\mathrm{n}} \\
& \mathrm{M}=\mathrm{Al}, \mathrm{Ga} \quad \mathrm{M}^{\prime}=\mathrm{Nb}, \mathrm{Tb} \quad \mathrm{M}_{2}=\mathrm{Zr}, \mathrm{Hf}, \mathrm{Sn}^{\mathrm{IV}} \\
& \mathrm{n}=1 \cdot \mathrm{E}=\mathrm{Li}, \mathrm{Na}, \mathrm{K}, \mathrm{Cs}, \mathrm{RMg}, \mathrm{R}_{3} \mathrm{Sn}, \mathrm{R}_{2} \mathrm{Sb}^{\mathrm{III}}, \mathrm{R}_{4} \mathrm{Sb}^{\mathrm{V}} \\
& \mathrm{n}=2: \mathrm{E}=\mathrm{Be}, \mathrm{Mg}, \mathrm{Ca}, \mathrm{Ba}, \mathrm{Cr}^{\mathrm{II}}, \mathrm{Mn}^{\mathrm{II}}, \mathrm{Fe}^{\mathrm{II}}, \mathrm{Co}^{\mathrm{II}}, \mathrm{Ni}^{\mathrm{II}}, \mathrm{Cu}^{\mathrm{II}} \text {, } \\
& \mathrm{Zn}, \mathrm{Cd}, \mathrm{Hg}^{\mathrm{II}}, \mathrm{R}_{2} \mathrm{Sn}^{\mathrm{IV}}, \mathrm{R}_{2} \mathrm{~Pb}^{\mathrm{IV}} \\
& \mathrm{n}=3: \mathrm{E}=\mathrm{Al}, \mathrm{Ga}, \mathrm{In}, \mathrm{Tl}{ }^{\mathrm{III}}, \mathrm{Sc}, \mathrm{Y}, \mathrm{Ln}, \mathrm{Cr}^{\mathrm{III}}, \mathrm{Mn}^{\mathrm{III}}, \mathrm{Fe}^{\mathrm{III}} \text {, } \\
& \mathrm{RSn}^{\mathrm{IV}} \\
& \mathrm{n}=4: \mathrm{E}=\mathrm{Sn}^{\mathrm{IV}}, \mathrm{Ce}^{\mathrm{IV}}, \mathrm{Th}^{\mathrm{IV}}, \mathrm{U}^{\mathrm{IV}} \text {. }
\end{aligned}
$$

The chelating alkoxometallates ligands like $\left\{\mathrm{M}(\mathrm{OR})_{4}\right\}^{-},\left\{\mathrm{M}^{\prime}(\mathrm{OR})_{6}\right\}^{-}$and $\left\{\mathrm{M}_{2}(\mathrm{OR})_{9}\right\}^{-}$may be, for brevity represented as $\mathrm{L}$ and the most common ones of these may be represented as indicated in the parenthesis after each specific ligand, $\left\{\mathrm{Al}\left(\mathrm{OPr}^{\top}\right)_{4}\right\}^{-}=\left(\mathrm{L}_{\mathrm{Al}}\right) ; \quad\left\{\mathrm{Nb}\left(\mathrm{OPr}^{\mathrm{l}}\right)_{6}\right\}^{-}=\left(\mathrm{L}_{\mathrm{Nb}}\right)$, $\left\{\mathrm{Ta}\left(\mathrm{OPr}^{3}\right)_{6}\right\}^{-}=\left(\mathrm{L}_{\mathrm{Ta}}\right)$ as well both together as $\left(\mathrm{L}_{\mathrm{M}^{\prime}}\right)$, and $\left\{\mathrm{Zr}_{2}\left(\mathrm{OPr}^{\mathrm{d}}\right)_{9}\right\}^{-}=\left(\mathrm{L}_{\mathrm{Zr}}\right)$.

In addition to the homoleptic derivatives, $\mathrm{EL}_{\mathrm{n}}$, partially substituted chlorometal alkoxometallates have also been synthesised more recently. For example, in the reactions ${ }^{36}$ of $\mathrm{BeCl}_{2}, \mathrm{MgCl}_{2}, \mathrm{ZnCl}_{2}$ and $\mathrm{CdCl}_{2}$ with $\mathrm{KL}_{\mathrm{Al}}$ in $1: 1$ molar ratio, the expected product $\left(\mathrm{ClBeL}_{\mathrm{Al}}\right)$ could be isolated, whereas in the other cases, the products appeared to disproportionate immediately into $\mathrm{MCl}_{2}$ and $\mathrm{M}\left(\mathrm{L}_{\mathrm{Al}}\right)_{2}$ :

$$
\begin{aligned}
\mathrm{BaCl}_{2}+\mathrm{KL}_{\mathrm{Al}} \stackrel{\mathrm{Pr}^{\prime} \mathrm{OH}}{\mathrm{MCl}_{2}+\mathrm{KL}_{\mathrm{Al}} \stackrel{\mathrm{Pr}^{\prime} \mathrm{OH}}{\mathrm{ClBeL}} \underset{\mathrm{Al}}{\longrightarrow} \mathrm{ClML}_{\mathrm{Al}}+\mathrm{KCl}} \\
1 / 2 \mathrm{MCl}\left(\mathrm{L}_{\mathrm{Al}}\right)_{2}+1 / 2 \mathrm{MCl}_{2}
\end{aligned}
$$

However, with a slight control of conditions, it has been possible to obtain not only the derivatives $\mathrm{ClZn}\left(\mathrm{L}_{\mathrm{Al}}\right)_{2}$, and $\mathrm{ClCd}\left(\mathrm{L}_{\mathrm{Al}}\right)_{2}$, but many other chloride-metal isopropoxymetallates by similar reactions between metal halides and alkali alkoxymetallates in different molar ratios, e.g. $\mathrm{ClCoL}_{\mathrm{Al}} ; \mathrm{ClCoL}_{\mathrm{M}}{ }^{\prime}$ and $\mathrm{ClCoL}_{\mathrm{Zr}}{ }^{37} ; \mathrm{ClFeL}_{\mathrm{M}^{\prime}}{ }^{38}$; $\mathrm{ClCuL}_{\mathrm{Al}} ; \mathrm{ClCuL}_{\mathrm{Ta}}$ and $\mathrm{ClCuL}_{\mathrm{Zr}}{ }^{39}, \mathrm{ClLa}\left(\mathrm{L}_{\mathrm{Zr}}\right)_{2}$ and $\mathrm{Cl}_{2} \mathrm{LaL}_{\mathrm{Zr}}{ }^{40}$.

In spite of the inherent difficulties ${ }^{41}$, it has been possible to elucidate the crystal structure of $\mathrm{Cd}(\mu-\mathrm{Cl})\left(\mathrm{L}_{\mathrm{Zr}}\right)_{2}{ }^{42}$ and $\left\{\operatorname{Pr}\left(\mathrm{L}_{\mathrm{Al}}\right)_{2}(\mu-\mathrm{Cl}) \operatorname{Pr}^{\prime} \mathrm{OH}\right\}_{2}{ }^{43}$; it is interestıng to find that both of these dimeric derivatives are chloride rather than isopropoxide bridged. These chloride-metal alkoxymetallates are easily converted into their alkoxide-metal alkoxometallates analogues by reacting these with alkali alkoxides in appropriate molar ratios.

In place of chloride as starting materials, $\left(\mathrm{NH}_{4}\right)_{2}$ $\mathrm{Ce}\left(\mathrm{NO}_{3}\right)_{6}$ has been used ${ }^{23}$ for the preparation of not only monometallic ceric alkoxide derivatives $\mathrm{Ce}\left(\mathrm{NO}_{3}\right)_{\mathrm{n}-\mathrm{x}}\left(\mathrm{OBu}^{\mathrm{l}}\right)_{\mathrm{x}} \cdot \mathrm{nTHF}$, but ${ }^{\prime}$ also bimetallic alkoxides with alkali metals, e.g.

$$
\begin{aligned}
\left(\mathrm{NH}_{4}\right)_{2} \mathrm{Ce}\left(\mathrm{NO}_{3}\right)_{6}+8 \mathrm{NaOBu}^{\mathrm{t}} \rightarrow \mathrm{Na}_{2} \mathrm{Ce}\left(\mathrm{OBu}^{\mathrm{t}}\right)_{6} \cdot 4 \mathrm{THF} \\
+2 \mathrm{NH}_{3}+6 \mathrm{NH}_{4} \mathrm{NO}_{3}+2 \mathrm{Bu}^{\mathrm{t}} \mathrm{OH}
\end{aligned}
$$

and

$$
\begin{array}{r}
2\left(\mathrm{NH}_{4}\right)_{2} \mathrm{Ce}\left(\mathrm{NO}_{3}\right)_{6}+13 \mathrm{NaOBu}^{\mathrm{t}} \rightarrow \mathrm{NaCe}_{2}\left(\mathrm{OBu}^{\mathrm{t}}\right)_{9} \\
+4 \mathrm{NH}_{3}+12 \mathrm{NaNO}_{3}+4 \mathrm{Bu}^{\mathrm{t} O H}
\end{array}
$$


Synthesis of tri- and higher heterometal alkoxides :

In spite of the significant success during 19671985 in the synthesis of a large number of stable bimetallic alkoxides with ligands like $\left\{\mathrm{Al}\left(\mathrm{OPr}^{\mathrm{d}}\right)_{4}\right\}^{-}=\left(\mathrm{L}_{\mathrm{Al}}\right),\left\{\left[\mathrm{Nb}\left(\mathrm{OPr}^{1}\right)_{6}\right\}^{-}=\left(\mathrm{L}_{\mathrm{Nb}}\right)\right\},\{\mathrm{Ta}-$ $\left.\left(\mathrm{OPr}^{1}\right)_{6}\right\}^{-}<\left(\mathrm{L}_{\mathrm{Ta}_{2}}\right)$ and $\left\{\mathrm{Zr}_{2}\left(\mathrm{OPr}^{1}\right)_{9}\right\}<\left(\mathrm{L}_{\mathrm{Zr}}\right)$, the preparation of the species with more than two metals in the same molecule was not even attempted in view of the general instability of such hetero- metallic derivatives. The first clue to the formation of a trimetallic alkoxide was detected in 1985 in the case of beryllium and was ascribed to the small size of beryllium, hindering the dispro- portionation of the species. The product , $\left(\mathrm{Pr}^{\prime} \mathrm{O}\right) \mathrm{Be}\left(\mu-\mathrm{OPr}^{\prime}\right)_{2} \mathrm{Al}\left(\mathrm{OPr}^{1}\right)_{2}$ was found on the basis of $n$ mr studies to dimerise on ageing ${ }^{44}$ into a product ${ }^{45}$ which could be represented as $\left(\mathrm{Pr}^{\prime} \mathrm{O}\right)_{2} \mathrm{Al}\left(\mu-\mathrm{OPr}^{\prime}\right)_{2} \mathrm{Be}\left(\mu-\mathrm{OPr}^{\mathrm{l}}\right)_{2} \mathrm{Al}\left(\mathrm{OPr}^{1}\right)_{2}$. This observa-tion led to the possibility of reactions of the following types, which were utilised for the isolation of trimetallic alkoxides ${ }^{6}$ for the first time in 1985 :

$$
\begin{gathered}
\left(\operatorname{Pr}^{1} \mathrm{O}\right)_{2} \mathrm{Al}\left(\mu-\mathrm{OPr}^{1}\right)_{2} \mathrm{Be}\left(\mathrm{OPr}^{1}\right)+\mathrm{Zr}\left(\mathrm{OPr}^{1}\right)_{4} \rightarrow \\
\left(\operatorname{Pr}^{1}\right)_{2} \mathrm{Al}(\mu \mathrm{OPr})_{2} \mathrm{Be}\left(\mu-\mathrm{OPr}^{1}\right)_{2} \mathrm{Zr}\left(\mathrm{OPr}^{1}\right)_{3} \\
\left(\mathrm{Pr}^{1}\right)_{2} \mathrm{Al}\left(\mu-\mathrm{OPr}^{1}\right)_{2} \mathrm{BeCl}+\mathrm{KNb} / \mathrm{Ta}\left(\mathrm{OPr}^{1}\right)_{6} \stackrel{-\mathrm{KCl}}{\rightarrow} \\
\left(\operatorname{Pr}^{1} \mathrm{O}\right)_{2} \mathrm{Al}(\mu-\mathrm{OPr})_{2} \mathrm{Be}\left(\mu-\mathrm{OPr}^{1}\right)_{2} \mathrm{Nb} / \mathrm{Ta}\left(\mathrm{OPr}^{1}\right)_{4}
\end{gathered}
$$

A large number of heterometal alhoxides of lanthanons ${ }^{17,46,47}$, zinc and cadmium ${ }^{48,49}$, tin(II) and (IV) ${ }^{50,51}$, manganese(II) ${ }^{52}$, iron(II) ${ }^{53}$, iron(III) $)^{54}$, cobalt(II) ${ }^{55}$, nickel(II) ${ }^{56}$ and copper(II) $)^{57}$ have since been synthesised and characterised in the research school of the author. These consist of a central metal atom ligated to one, two or more of chelating ligands, like $\mathrm{L}_{\mathrm{Al}}, \mathrm{L}_{\mathrm{Zr}}, \mathrm{L}_{\mathrm{Nb}}$ or $\mathrm{L}_{\mathrm{Ta}}$ in addition to two other similar ligands, e.g. $\left\{\mathrm{Zr}\left(\mathrm{OPr}^{1}\right)_{5}\right\}$ and $\left\{\mathrm{Al}\left(\mathrm{OBu}^{t}\right)_{4}\right\}^{-}$, which appear to confer greater stability to a number of heterometal alkoxide systems ${ }^{17,56}$. The general method of synthesis could be represented as

$$
\begin{aligned}
& \mathrm{MCl}_{\mathrm{n}}+\mathrm{xKL}_{\mathrm{Al}} \ldots \mathrm{xKCl} \ldots \mathrm{MCl}_{\mathrm{n}-\mathrm{x}}\left(\mathrm{L}_{\mathrm{A}}\right)_{\mathrm{x}} \\
& \mathrm{MCl}_{\mathrm{n}-\mathrm{x}}\left(\mathrm{L}_{\mathrm{Al}}\right)_{\mathrm{x}}+\mathrm{yKL}_{\mathrm{Zr}}-\overline{\mathrm{yKCl}} \mathrm{MCl}_{\mathrm{n}-\mathrm{x}-\mathrm{y}}\left(\mathrm{L}_{\mathrm{Al}}\right)_{\mathrm{x}}\left(\mathrm{L}_{\mathrm{Zr}}\right)_{\mathrm{y}}
\end{aligned}
$$

$$
\begin{gathered}
\mathrm{MCl}_{\mathrm{n}-\mathrm{x}-\mathrm{y}}\left(\mathrm{L}_{\mathrm{Al}}\right)_{\mathrm{x}}\left(\mathrm{L}_{\mathrm{Zr}}\right)_{\mathrm{y}}+\mathrm{zKL}_{\mathrm{Nb}} \overrightarrow{-\mathrm{zKCl}} \\
\mathrm{MCl}_{\mathrm{n}-\mathrm{x}-\mathrm{y}-\mathrm{L}}\left(\mathrm{L}_{\mathrm{Al}}\right)_{\mathrm{x}}\left(\mathrm{L}_{\mathrm{Zr}}\right)_{\mathrm{y}}\left(\mathrm{L}_{\mathrm{Nb}}\right)_{\mathrm{z}}
\end{gathered}
$$

and so on.

The intermediate chloride derivatives, e.g. M$\mathrm{Cl}_{\mathrm{n}-\mathrm{x}-\mathrm{y}-\mathrm{z}}\left(\mathrm{L}_{\mathrm{Al}}\right)_{\mathrm{x}}\left(\mathrm{L}_{\mathrm{Zr}}\right)_{\mathrm{y}}\left(\mathrm{I}_{\mathrm{Nb}}\right)_{\mathrm{z}}$ have been isolated in a few cases and characterised even by $X$-ray crystallography ${ }^{42,43}$. These can be further reacted with reagents like $\mathrm{KOR}$ or Kacac to yield products of the type, $\mathrm{MX}_{\mathrm{n}-\mathrm{x}-\mathrm{y}-\mathrm{Z}}\left(\mathrm{L}_{\mathrm{Al}}\right)_{\mathbf{x}}\left(\mathrm{L}_{\mathrm{Zr}}\right)_{\mathrm{y}}\left(\mathrm{L}_{\mathrm{Nb}}\right)_{z}$, where $\mathrm{X}$ is either an alkoxy ligand like (OEt), (OPr) or $\left(\mathrm{OBu}^{t}\right)$ or a $\beta$-diketonato like acetylacetonate (acac) ligand.

Heterometal alkoxides as precursors in the sol-gel process

Much before Mehrotra ${ }^{11}$ drew pointed attention to the advantages of employing the heterometal alkoxides, Dislich ${ }^{10}$ had concluded that the ultrahomogeneity of the ceramic glasses obtained by the use of a number of different metal alkoxides could not be ascribed merely to more intimate physical mixing in solution, but it pointed towards new 'chemical bond' formation. Obviously, the use of preformed heterometal alkoxides should lead to a more homogeneous product than that expected from randomised chemical bond formation in the initial solution of constituent metal alkoxides.

In the only earlier use $\mathrm{e}^{25}$ of a bimetallic alkoxide $\mathrm{Mg}\left\{\mathrm{Al}\left(\mathrm{OPr}^{\mathrm{d}}\right)_{4}\right\}_{2}{ }^{20}$ for the preparation of $\mathrm{MgAl}_{2} \mathrm{O}_{4}$, the initial framework of the $\mathrm{Mg}\left\{\mathrm{Al}\left(\mathrm{OPr}^{1}\right)_{4}\right\}_{2}$ was shown to remain intact during the gel formation. The solubility of tetraisopropoxyaluminates of bivalent metals (e.g., $\mathrm{Mg}, \mathrm{Ca}, \mathrm{Sr}, \mathrm{Ba}^{20}, \mathrm{Mn}^{1 \mathrm{II}}{ }^{52}$, $\mathrm{Co}^{115}, \mathrm{Ni}^{11} 58$ and $\mathrm{Cu}{ }^{11}{ }^{59}$ ) had indicated that these did not get dissociated in solution to yield the insoluble isopropoxides of the bivalent metals. This was further confirmed by their almost quantitative volatilisation unchanged at temperatures much higher than that of $\mathrm{Al}\left(\mathrm{OPr}^{1}\right)_{3}$, indicating that the bimetallic alkoxide did not depict any tendency of dissociating into component alkoxides. 
Although no $X$-ray crystal structure elucidation of any homoleptic tetraisopropoxyaluminate is so far available, yet the crystal structure of $\operatorname{Pr}\left\{\mathrm{Al}\left(\mathrm{OPr}^{\mathrm{l}}\right)_{4}\right\}_{2}\left(\mathrm{Pr}^{\mathrm{i} O H}\right)(\mu-\mathrm{Cl})_{2}{ }^{43}$ shows clear tetraisopropoxyaluminate units. The physcochemical evidence for a similarity in the structures of $\mathrm{Ln}\left\{\mathrm{Al}\left(\mathrm{OPr}^{\mathrm{l}}\right)_{4}\right\}_{3}{ }^{26}$ and $\mathrm{Al}\left\{\mathrm{Al}\left(\mathrm{OPr}^{1}\right)_{4}\right\}_{3}{ }^{27}$ has been emphasised already. The framework of $\mathrm{Al}\left(\mathrm{OPr}^{1}\right)_{4}^{-}$ units in $\operatorname{Ln}\left\{\mathrm{Al}\left(\mathrm{OPr}^{\mathrm{i}}\right)_{4}\right\}_{3}$ has been confirmed by the following types of reactions with methanol and acetaylacetone (hacac) ${ }^{27}$ :

$$
\begin{array}{r}
\mathrm{Ln}\left\{\left(\mu-\mathrm{OPr}^{\mathrm{l}}\right)_{2} \mathrm{Al}\left(\mathrm{OPr}^{1}\right)_{2}\right\}_{3}+6 \mathrm{MeOH} \\
\mathrm{Ln}\left\{(\mu-\mathrm{OMe})_{2} \mathrm{Al}\left(\mathrm{OPr}^{\mathrm{i}}\right)_{2}\right\}_{3} \\
+6 \mathrm{Hacac} \\
\mathrm{Ln}\left\{\left(\mu-\mathrm{OPr}^{\mathrm{i}}\right)_{2} \mathrm{Al}\left(\mathrm{OPr}^{1}\right)_{2}\right\}_{3} \stackrel{+6}{\left.\mathrm{Ln}\left\{\mu-\mathrm{OPr}{ }^{\mathrm{i}}\right)_{2} \mathrm{Al}(\mathrm{acac})_{2}\right\}_{3}} \\
\text { Soluble monomeric } \\
\text { volatile products }
\end{array}
$$

In has presentation" at the "Reno Symposium of Material Research Society (1988)', Mehrotra had emphasised the potential applications of the $\mathrm{S}-\mathrm{G}$ process in preparation of (i) $\mathrm{MNbO}_{3}$ from $\mathrm{M}\left\{\mathrm{Nb}(\mathrm{OR})_{6}\right\}$ (where $\mathrm{M}=$ alkali metal) ${ }^{60}$, (ii) $\mathrm{LnAl}_{3} \mathrm{O}_{6}$ from $\left.\mathrm{LnAl}\left(\mathrm{OPr}^{\mathrm{i}}\right)_{43}^{27}\right\}$, (iii) $\mathrm{ZnAl}_{2} \mathrm{O}_{5}$ from $\left(\mathrm{Pr}^{1} \mathrm{O}\right)_{2} \mathrm{Zr}\left\{\mathrm{Al}\left(\mathrm{OPr}^{1}\right)_{4}\right\}_{2}^{32}$, (iv) $\mathrm{BaTiO}_{3}$ from $\mathrm{Ba}$ $\left[\mathrm{Ti}(\mathrm{OR})_{6}\right]^{61,62}$ and many others from more complicated systems. Out of these, the preparation of crystalline ferroelectric and piezoelectric $\mathrm{LiNbO}_{3}$ fibres from $\mathrm{LiNb}(\mathrm{OEt})_{6}$ has been contirmed ${ }^{63}$. Similarly, the preparation of crystalline $\mathrm{LiNb}_{\mathrm{x}}$ $\mathrm{Ta}_{1-\mathrm{x}} \mathrm{O}_{3}(\mathrm{O} \times 1)$ films has been achieved ${ }^{64}$ from the hydrolysis of a mixture of $\mathrm{Li}\left\{\mathrm{Nb}(\mathrm{OEt})_{6}\right\}$ and $\mathrm{Li}\left\{\mathrm{Ta}(\mathrm{OEt})_{6}\right\}$ in the required molar ratio. Another important relaxor ferroelectric material, $\mathrm{Pb}\left(\mathrm{Mg}_{1 / 3^{-}}\right.$$\left.\mathrm{Nb}_{2 / 3}\right) \mathrm{O}_{3}$ has been prepared ${ }^{65}$ by co-hydrolysis of the bimetallic alkoxide $\mathrm{Mg}\left\{\mathrm{Nb}(\mathrm{OEt})_{6}\right\}_{2}{ }^{61}$ with $\mathrm{Pb}\left(\mathrm{OBu}^{\mathrm{t}}\right)_{2}{ }^{66}$ by the sol-gel procedure in the form of an aerogel ${ }^{67}$.

In the preparation of $\mathrm{KNbO}_{3}$ ceramic disc from $\mathrm{KNb}(\mathrm{OEt})_{6}{ }^{68}$, Mackenzie and coworkers ${ }^{69}$ showed that a higher level of homogenenty is obtained by the use of preformed bunetallic alkoxide rather than a mixture of the -umponent $\mathrm{KOEt}$ and $\mathrm{Nb}(\mathrm{OEt})_{5}$ as precursor.
With the advent of superconducting materials, e.g. $\mathrm{YBa}_{2} \mathrm{Cu}_{3} \mathrm{O}_{7-\mathrm{x}}$, concerted efforts have been directed to prepare soluble alkoxides of the bivalent metals like $\mathrm{Ba}$ and $\mathrm{Cu}$. In addition to the success in this direction by using chelating polyalkoxometallate ligands, simpler chelating alcohols like methoxyethanol $\mathrm{CH}_{3} \mathrm{OC}_{2} \mathrm{H}_{4} \mathrm{OH}^{70}$ or ethanoldimethylamine $\mathrm{Me}_{2} \mathrm{NC}_{2} \mathrm{H}_{4} \mathrm{OH}^{5}$ has been empolyed, followed by using ${ }^{71}$ these soluble alkoxy derivatives for the preparation of $\mathrm{YBa}_{2} \mathrm{Cu}_{3} \mathrm{O}_{7-x}$ films. Another bimetallic alkoxide which has been used for superconducting film is $\mathrm{Ba}_{2} \mathrm{Cu}_{2}(\mathrm{OR})_{4}(\mathrm{acac})_{4} 2 \mathrm{HOR} \quad\left(\mathrm{R}=\mathrm{CH}_{2} \mathrm{CH}_{2} \mathrm{OCH}_{3}\right)^{72}$. $\mathrm{Sakka}^{73}$ has reviewed the literature on the sol-gel processes for superconductors.

\section{Acknowledgement}

The author is grateful to scores of his doctoral students and post-doctoral as well as teacher colleagues for their enlightening cooperation and innovativeness in spite of adverse circumstances. Financial assistance from the D.S.T. and C.S.I.R., New Delhi, is also gratefully acknowledged.

\section{References}

1. H MeErwein and T. Bersin, Ann., 1929, 476, 113.

2. R C. Mehrotra and A Mlhrotra, Inorg. Chim. Acta Rev., 1971, 5, 127.

3. W. G. Bartley and W. Wardiaw, J. Chem. Soc., 1958, 421.

4. D. C. Baradley, R. C. Mehrotra and D. P. Gaur, "Metal Alkoxides", Academic, London, 1978.

5. R. C. Menrotra, Adv. Inorg. Chem. Radiochem., 1983, 26, 269

6. R C Mrhrotra and M. Aggarwal, Polyedron. 1985 , 4, 845.

7. R K. Dubey, A. Singh and R. C. Ml.hro1RA, J. Organomet. Chem. 1988, 341, 569

8. R K Dubey, A. Shah and R. C Mlhroira, Recul, 1988, 107, 237.

9. R C. Mlhrotra, J. Non-Cryst. Solids. 1988, 1, 100.

10. H Dislich, Angew. Chem. Int. Ed. Engl., 1971, 10, 363.

11. R C. Mrhioira, Mat. Res. Soc. Symp. Proc., 1988, 121, 81

12. R. C Mi hrotra in "Sol-Gel Science and Techlonogy". eds. M. A. AEgCrTer, M. Jarrelicci. JR, D F SOUZA and E. D. ZANOT7O, World Scientific, Singapore, 1989, p. 24. 
13. D. C. Baradley, Chem. Rev., 1989, 89, 1317.

14. K. G. Caulton and L. G. Pfalzgraf, Chem. Rev., 1990, 90, 969.

15. R. C. Mehrotra, Chemtracts, 1990, 2, 389.

16. R. C. MEhrotra, J. Organomet. Chem. (Russian), 1990, 3, 729.

17. R. C. Mehrotra, A. Singh and U. M. Tripathi, Chem. Rev., 1991, 91, 1287.

18. R. C. MeHrotra, Nat. Acad. Sci. Lett., 1991, 14, 153.

19. R. C. Mehrotra, Indian J. Chem., Sect. A, 1992, 31, 492.

20. P. N. Kapoor and R. C. Mehrotra, Coord. Chem. Rev., 1974, 14, 1 .

21. R. C. Mehrotra, Proc. Indian Nat. Sci. Acad., 1976, 42, 1.

22. R. C. Mehrotra, Kemiai Kozlemenyck, 1975, 45, 197.

23. W. J. Evans, T. J. Deming, J. M. Olofson and J. W. Zlller, Inorg. Chem., 1989, 28, 4027.

24. F. A. CotTon, D. O. MARier and W. Schevotzer, Inorg. Chem., 1984, 25, 4211 .

25. R. G. Jones, E. B. Bindschadler. D. Blume, G. Karmas, G. A. Marten, J. R. Thirtle and H. Gilman, J. Am. Chem. Soc., 1956, 78, 6027.

26. R. C. Mehrotra, J. M. Batwara and P. N. Kapoor, Coord. Chem. Rev., 1980, 31, 67.

27. N. Ya Tuvova, V. A. Kozunov, A. L. YanovashiL, N. G. BOKIL, YU. T. STRUCHKOR and B. L. TAMOPOLSKII, J. Inorg. Nucl. Chem., 1979., 41, 5.

28. L. M. BROWN and K. S. MAZDIYASNI, Inorg. Chem., 1978, 9, 2783.

29. O. Poncelet, W. J. Sartain, L. B. Pfalzgraf, K. Folting and K. G. CAulton, Inorg. Chem., 1989, 28, 263.

30. R. C. MEhrotra, Chemtracts, 1990, 2, 143.

31. J. G. Reiss and L. G. Pfalzgraf, Bull. Soc. Chim. Fr., 1968, 240, 4348.

32. R. C. MEhrotra, R. JAIN and A. K. RAI, J. Inorg. Chem. (China), 1987, 3, 96.

33. S. Govil, P. N. KapOOR and R. C. MEHROTRA, Inorg. Chum. Acta, 1975, 15, 43.

34. R. K. Dubey, A. Singh and R. C. Mehrotra, Inorg. Chim. Acta, 1986, 118, 151.

35. R. JAIN, A. K. RAI and R. C. MEHROTRA, Z. Naturforsch., Tell B, 1985, 40, 1371 .

36. R. C. Mfhrotra, M. Aggrawal and C. K. Sharma, Synth. Kew I Inorg. Metal-Org. Chem., 1984, 13, 571.

37. R. K. Di $\|$ Y, A. SINGH and R. C. MEhrotra, Inorg. Chim. Acta, 1988, 143, 169

38. A. ShaH, A. Singh and R. C. Mehrotra, Indian J. Chem., Sect. A, 1988, 27, 372 .

39. R. C. ChHipA, A. Singh and R. C. Mehrotra, Synth. React. Inorg. Metal-Org. Chem., 1990, 20, 989.
40. U. M. Tripathi, A. Singh and R. C. Mehrotra, Polyhedron, 1991, 10, 949.

41. D. C. Bradley, Phil. Trans. R. Soc. London, Ser. A, 1990, 330, 167.

42. S. Sogani, R. Bohra, M. Nattemeyer, A. Singh and R. C. Mehrotra, J. Chem. Soc., Chem. Commun., 1991, 738.

43. U. M. Tripathi, A. Singh, R. C. Mehrotra, S. C. Geel, M. Y. Chinng and W. E. Buhro, J. Chem. Soc., Chem. Commun., 1992, 152.

44. R. C. Mehrotra, J. Indian Chem. Soc., 1953, 30, 585.

45. M. Aggrawal and R. C. Mehrotra, Polyhedron, 1985, 4, 1141 .

46. U. M. Tripathi, A. Singh and R. C. Mrhrotra. Polyhedron, 1991, 10, 949.

47. U. M. Tripathi, Ph.D. Thesis, University of Rajasthan, 1992.

48. S. Sogani, A. Singh and R. C. Mehrotra, Main Group Met. Chem., 1992, 15, 197; Indian J. Chem., Sect. A, 1993, 32, 345.

49. S. SogANı, Ph.D. Thesis, University of Rajasthan, 1992.

50. S. Mathur, A. Singh and R. C. Mehrotra, Polyhedron, 1992, 11, 341.

51. S. MathuR, Ph.D. Thesis, University of Rajasthan, 1992.

52. R. K. Dubey, A. Singh and R. C. Mehrotra, Indian J. Chem., Sect. A, 1992, 31, 156.

53. R. Gupta, A. Singh and R. C. Mehrotra, Indian J. Chem., Sect. A, 1991, 30, 592.

54. R. Gupta, A. Singh and R. C. Mehrotra, New J. Chem., 1991, 15, 665; Indian J. Chem., Sect. A, 1993, 32. 310.

55. G. GARG, A. Singh and R. C. Mehrotra, Indian J. Chem., Sect. A, 1991. 30, 688, 866; Synth. React. Inorg. MetalOrg. Chem., 1991, 21, 1047.

56. G. Garg, R. K. Dubey, A. Singh and R. C. Mehrotra. Polyhedron, 1991, 10, 1733.

57. R. C. ChHipa, A. Singh and R. C. Mehrotra, Synth. React. Inorg. Metal-Org. Chem., 1990, 20, 989; Indian J. Chem., Sect. A, 1991, 30, 1024.

58. R. C. Mehrotra and J. V. Singh, Can J. Chem., 1984, 62, 1003.

59. R. C. Mehrotra, M. M. Agrawal and P. N. Kapoor, J. Chem. Soc., 1968, 1203.

60. R. C. Mehrotra and J. V. Singh, Z. Anorg. Allgem. Chem., 1984, 322, 211.

61. S. Govil, P. N. KaPOOR and R. C. MEhrotrA, J. Inorg. Nucl. Chem., 1976, 38, 172.

62. J. RAI, Ph.D. Thesis, University of Rajasthan, 1992.

63. S. HiRano, T. Hayashi, K Nosaki and K. Kato, $J$ Am. Ceram. Soc., 1989, 72, 707.

64. S. Hirano and K. Kato, Bull. Chem. Soc. Ipn., 1989, 62, 429; Solid State Ionics, 1989, 32-33, 765.

65. F. Chaput, J. Boilot, M. Lejeune, R. PAPIERnik and 
MEHROTRA : HETEROMETAL ALKOXIDES AS PRECURSORS IN THE SOL-GEL PROCESS

L. G. Hubert-Pfalzgraf, J. Am. Ceram. Soc., 1989, 72, 1335.

66. R. PAPIERniK, L. G. Hubert-Pfalzgraf, A.M. Massiani, F. Chaput, J. P. Boilot, O. Bouquin and Lejeune, 'Am. Chem. Soc. Meeting', Los Angeles, 1988, Paper No. Inorg. 230 .

67. R. C. Mehrotra, J. Non-Cryst. Solids, 1992, 145, 1.

68. R. C. Mehrotra, M. M. Agrawal and P. N. Kapoor, J. Chem. Soc. (A), 1968, 2673.
69. A. NAZERI-Eshighi, A. X. KuANG and J. D. Mackenzine, J. Mat. Sci., 1990, 25, 3333.

70. S. C. Goel, K. S. Kramer, P. C. Gibbons and W. E. BuHro, Inorg. Chem., 1989, 28, 1619.

71. G. Kordas, J. Non-Cryst. Solids, 1990, 121, 436.

72. N. N. Sauer, E. Gracia, K. V. Salazar, R. R. Ryan and J. A. Marten, J. Am. Chem. Soc., 1990, 112, 1524.

73. S. SaKKa, J. Non-Cryst. Solids, 1990, 121, 417. 
